Таким образом, электронные учебно-методические пособия представляют собой электронную справочную систему, а также являются самостоятельной программой, применяемой для дистанционного обучения работников, а также, для усовершенствования кадров к горнодобывающей промышленности.

\title{
Гендерное равенство: вчера, сегодня, завтра
}

\author{
Ревизоров О.А., учащийся, \\ МОУ Гимназия №1, г. Нерюнгри \\ E-mail: j-h713@mail.ru
}

Научный руководитель: учитель истории и обществознания Труханович О.В.

Вопросы положения женщин в обществе, расширение их прав и возможностей, проблемы вовлечения женщин в общественную жизнь в качестве активных их участников являются актуальными для многих стран. Своеобразие современного этапа развития российского общества, динамизм социальных процессов, обострение социальных противоречий не могли не отразиться на отношениях между полами, обозначив интерес к гендерной проблематике. Учитывая все аспекты экономического, политического и социального прогресса на сегодняшний день можно однозначно определить, что роль женщины в обществе уже не имеет четких границ. Отсутствие единого социального значения, с которым женщина могла идентифицироваться,

Самоидентификация современной женщины осуществляется через взаимодействие патриархатных принципов, опирающихся на длительную социальную и культурную традицию, и принципов эгалитаризма, являющихся результатом женской борьбы за равноправие. Эмансипация женщины, происходящая в короткий по историческим меркам промежуток времени, до сих пор не может устранить ценности патриархата ни в обществе и культуре, ни в женском самосознании.

Задачи исследования:

1. Выяснить, имеют ли женщины равные права и обязанности с мужчинами.

2. Задачи.

3. Проанализировать имеют ли женщины равные права в обществе с мужчинами.

4. Проанализировать какие противоречия в правах между женщинами и мужчинами существуют в данный момент, в обществе Российской Федерации.

5. Определить основные обязанности женщин и мужчин в современном обществе Российский Федерации, для выявления фактов неравенства полов.

На основе изученного материала, проведенного анализа имеющейся информации в ходе работы над темой определены основные аспекты работы:

- Что же такое равенство полов?

Равенство полов, а также равноправие полов, равенство мужчин и женщин, равноправие мужчин и женщин, гендерное равенство, гендерное равноправие, эгалитарная семья́, гендерная элитарность и т.д.

Есть люди, которые стремятся не только к равенству, но и тождеству (свойство быть таким же) мужчины и женщины. Наделяя обоих одними и теми же правами, они 
возлагают на них одни и те же обязанности. Они хотят, чтобы мужчины и женщины вместе одинаково и трудились, и развлекались.

Критики концепции равенства, признавая в общем плане суть концепции, дают, однако другое её определение: Равенство полов есть возможность развития женщины как женщины, а мужчины как мужчины.

- Исторический аспект базируется на естественном процессе женской эмансипации. Положение женщины в семье до революции регулировалось законодательством, основанном на принципах Домостроя и положениях Священного писания.

В XIX-начале XX в. в России господствовала консервативно-патриархальная концепция, в рамках которой женщины занимали подчинённое положение. Эта концепция являлась основой законодательства, поддерживалась высшими органами государственной власти, а также значительной частью населения страны. Её теоретической и нравственной опорой являлось христианское учение, согласно которому жена сотворена после мужа - создана для мужа, не только помощница для мужа, но помощница «подобная ему». В научной и общественной среде России XIX в. появляются теории о природных предпосылках неполноценности женщин, в соответствие с которыми заявлялось, что женщины физически слабее мужчин и менее умны, что предполагает ограничение их в правах.

В конце XIX в связи с ростом промышленного производства и техническим усовершенствованием рабочего процесса, значительно возросло количество женского труда на фабриках, заводах и в ремесленных мастерских. Это привело к всплеску интереса к вопросам, связанным с охраной прав трудящихся женщин. Законодательство России не предусматривало отпуск для беременных женщин, поддержку роженицам со стороны государства и владельцев фабрик и предприятий, правовую охрану матерей, имеющих малолетних детей.

В первые годы советской власти были приняты новые законы о разводе и о внебрачном ребенке, о праве женщины на иск к отцу ребенка для его обеспечения. Они означали женскую вседозволенность, разрушение традиционной семьи, введение материнской семьи и закрепощение мужчины с помощью того, что называется "алиментами". В 1926 г. в "Кодекс о семье" было внесено положение о необязательности законной регистрации брака, брак признавался таковым по самому факту сожительства мужчины и женщины. Развод давался по первому заявлению одной из сторон, отцовство устанавливалось на основании заявления матери.

- Анализируя статистические данные процессов и явлений общественной жизни на сегодняшний день получены следующие выводы:

1. Мужчин в России 66.050.000, а женщин 76.815.000

2. Средняя продолжительность жизни мужчин в России на 11 лет меньше, чем у женщин.

3. Ежегодно более одного миллиона (1.000.000) мужчин умирают от болезней сердца и сосудов, что примерно в десять раз(10раз) больше, чем женщин (100.000)

4. Смертность мужчин в молодом возрасте (15лет-24года) в три раза превышает смертность женщин.

5. В возрасте семидесяти (70) лет и более количество мужчин в четыре (4раза) раза меньше, чем женщин.

6. От травм, полученных на производстве, мужчин погибает в десять (10раз) раз больше, чем женщин. 
7. От всех видов насилия мужчин погибает в два (2раза) раза больше, чем женщин.

8. Ежегодно заканчивающих жизнь самоубийством мужчин в шесть (6раз) раз больше, чем женщин.

9. $\quad 70 \%$ страдающих наркоманией - мужчины (обычно молодые мужчины).

10. 80\% больных СПИДом - также мужчины (чаще всего это последствие наркомании).

11. 85\% всех бездомных - мужчины.

12. Мужчины составляют $98 \%$ всех обитателей тюрем в России.

13. Наказание за нарушение УК РФ для женщин мягче в 8 раз. Женщина не может сидеть в тюрьме пожизненно, а также имеет на один метр в камере больше. Также она не может находится в колонии строгого режима.

14. Если женщина после родов убила своего ребенка это карается только 1 годом условно

15. Решение об аборте принимает женщина, муж влияния оказать не может.

16. Государственные должности и должности гражданской службы занимали 561.100 женщин и 225.300 мужчин.

17. Законодательная власть: 7400 женщин, 5000 мужчин

18. Исполнительная власть: 438400 женщин, 185600 мужчин

19. Судебная власть и прокуратура: 106900 женщин, и только 29300 мужчин

20. Муниципальные должности и должности муниципальной службы: 267000 женщин, 85300 мужчин. Большая часть воспитателей и учителей женщины, что оказывает влияние на детей

Констатируя полученные данные, выяснилось, что женщины в современном мире, в условиях социального равноправия живут лучше и дольше чем мужчины. С чем это связано? Условия жизни и работы женщин являются более благоприятными на законодательном уровне, чем условия жизни и работы мужчины, а также женщины выходят на обеспечение государством гораздо раньше мужчин. Имеют различные привилегии, и меньше обязанностей, данное утверждение основано на проведенном анализе:

Bоенные обязанности. Защита Отечества является долгом и обязанностью гражданина Российской Федерации. Однако женщины, несмотря на это необязательны служить в армии РФ.

Рождение ребенка. Если взять даже исторический уклад человечества, в частности, мнение известных философов, то женщина считалась лишь сосудом для воспроизводства человечества, из чего никак не следовало, что она имеет все права и не имеет обязанностей. Сосуду, как фабрике, не нужны права, и сосуд не является более ценным, чем его пользователь. А наоборот, пользователь сосуда является главным, а сосуд существует лишь для его удобства, и в прошлом женщины не имели равных прав, и имели обязанности, в некоторых случаях - и военную. Сейчас основная масса мужчин живут хуже, или так же, как женщины, по крайней мере мало кто из мужчин живет за счет супруги и может не работать, в отличие от женщин. На данный момент женщина не обязана юридически рожать ребенка.

Основным выводом работы является жизнеутверждающий факт - женщины имеют больше прав и меньше обязанностей как в правовом, так и общественном плане. В результате попрания прав мужчин появились организации по защите прав мужчин. 
И существует вероятность, что в недалеком будущем уже мужчины станут бороться за уравнение в социальных возможностях.

Список литературы:

1. Здравомыслова О.М. Представление о гендере связано с осознанием личности / О.М. Здравомыслова, Н. Кагай // Университет Каггари - Горбачев - Фонд,ИСЭПН РАН. - М., 2005. - С. 56 - 59.

2. Исакова Е.В. Влияние гендерных стереотипов на трудовую деятельность / Е.В. Исакова - М.: ГУ ВШЭ, МАКС Пресс, 2007. -С. 198-212.

3. Батлер Дж. Случайно сложившиеся основания: феминизм и вопрос о «постмодернизме» //Введение в тендерные исследования. Ч. ІІ: Хрестоматия. -Харьков: ХЦГИ, 2001; СПб.: Алетейя, 2001. С. 235-258.

4. Брандт Г. Феминизм и российское сознание //Феминистская теория и практика: Восток-Запад: Материалы международной научно-практической конференции. СПб., 1996. - C. 71-72.

\section{Профессиональная компетентность педагога как средство обеспечения защиты прав детей от семейного насилия в условиях ДОО}

Руфова Ю.С., студентка, Вилюйский педагогический колледж имени Н.Г. Чернышевского, 2. Вилюйск

Научный руководитель: к.n.н. Борисова 3.H. E-mail: vpc_proekt@mail.ru

По СМИ все чаще и чаще передают новости о самых разных нарушениях прав детей. Последние новости: учащение педофилии, смерть детей от обморожения и переохлаждения и т.д. Следовательно, необходимо активизировать работу педагогов по защите прав детей от семейного насилия.

Гипотеза: Защита детей от семейного насилия будет обеспечена, если деятельность воспитателя детского сада по данной проблеме будет профессионально компетентной.

Объект нашего исследования - защита прав детей от семейного насилия, а предмет - изучения является деятельность педагога, его компетенция по изучаемой проблеме.

Цель работь - изучить и оценить содержание профессиональной компетентности педагогов в обеспечении защиты прав детей от семейного насилия.

На 1 этапе изучены методом педагогического анализа психолого-педагогические и социальные аспекты обеспечения защиты прав детей педагогами детского сада. Нами изучены труды Э.Ф. Зеер, Л.В. Лавриненко, Д. Карнеги и других. Ими установлено, что именно в период дошкольного детства у всех детей, живущих в поликультурном пространстве происходит обезличенное формирование личности, ведущей к нарушению этнического самосознания. По мнению большинства исследователей, этническая идентификация должна начинаться с малых лет, при этом уважительное отношение к 